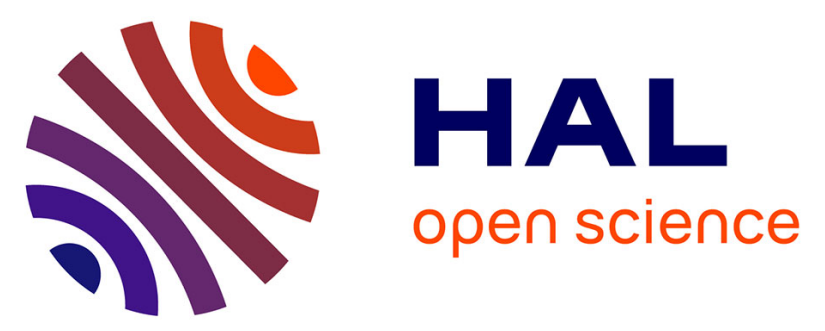

\title{
Influence of hydrogen-oxidizing bacteria on the corrosion of low carbon steel: Local electrochemical investigations.
}

Rebeca Leite de Souza Moreira, Marta K Schütz, Marie Libert, Bernard Tribollet, Vincent Vivier

\section{- To cite this version:}

Rebeca Leite de Souza Moreira, Marta K Schütz, Marie Libert, Bernard Tribollet, Vincent Vivier. Influence of hydrogen-oxidizing bacteria on the corrosion of low carbon steel: Local electrochemical investigations.. Bioelectrochemistry, 2014, 97, pp.69-75. 10.1016/j.bioelechem.2013.10.003 . hal01011763

\section{HAL Id: hal-01011763 \\ https: / hal.sorbonne-universite.fr/hal-01011763}

Submitted on 6 Nov 2014

HAL is a multi-disciplinary open access archive for the deposit and dissemination of scientific research documents, whether they are published or not. The documents may come from teaching and research institutions in France or abroad, or from public or private research centers.
L'archive ouverte pluridisciplinaire HAL, est destinée au dépôt et à la diffusion de documents scientifiques de niveau recherche, publiés ou non, émanant des établissements d'enseignement et de recherche français ou étrangers, des laboratoires publics ou privés. 


\title{
INFLUENCE OF HYDROGEN-OXIDIZING BACTERIA ON THE CORROSION
}

\section{OF LOW CARBON STEEL: LOCAL ELECTROCHEMICAL INVESTIGATIONS}

\author{
Rebeca Moreira $^{\mathrm{a}, \mathrm{b}}$, Marta K. Schütz ${ }^{\mathrm{c}}$, Marie Libert ${ }^{\mathrm{c}}$, Bernard Tribollet ${ }^{\mathrm{a}, \mathrm{b}}$, \\ Vincent Vivier ${ }^{\mathrm{a}, \mathrm{b}, *}$
}

${ }^{a}$ CNRS, UPR15, Laboratoire Interfaces et Systèmes Electrochimiques, F-75005 Paris, France

${ }^{b}$ UPMC Univ Paris 06, UPR15, LISE, 4 place Jussieu, F-75005 Paris, France

${ }^{c}$ CEA / DEN / DTN / SMTM / LMTE, 13108 Saint Paul lez Durance, France

\author{
* Corresponding author. \\ V. Vivier Tel.: +33-1-44274158; fax: 33-1-44274074 \\ E-mail address: vincent.vivier@upmc.fr
}

\begin{abstract}
Low carbon steel has been considered a suitable material for component of the multi-barrier system employed on the geological disposal of high-level radioactive waste (HLW). A non negligible amount of dihydrogen $\left(\mathrm{H}_{2}\right)$ is expected to be produced over the years within the geological repository due to the anoxic corrosion of metallic materials and also due to the water radiolysis. The influence of the activity of hydrogen-oxidizing bacteria (HOB) and ironreducing bacteria (IRB) on carbon steel corrosion is considered in this study because of the high availability of energetic nutriments $\left(\mathrm{H}_{2}\right.$, iron oxides and hydroxides) produced in anoxic disposal conditions. Local electrochemical techniques were used for investigating the activity of IRB as a promoter of local corrosion in presence of $\mathrm{H}_{2}$ as electron donor. A local consumption of $\mathrm{H}_{2}$ by the bacteria has been evidenced and impedance measurements indicate the formation of a thick layer of corrosion products.
\end{abstract}

Keywords: biocorrosion, carbon steel, hydrogen-oxidizing bacteria (HOB), SECM, Local Electrochemical Impedance Spectroscopy 


\section{Introduction}

The safe disposal of radioactive waste is a major concern for the nuclear energy industry. The high level radioactive waste (HLW) should be maintained for years in deep clay formations in order to prevent the migration of radionuclides. Thus, many different kinds of materials such as carbon steel, stainless steel, glass, concrete and clay are employed on the waste repository aiming to act as a multi-barrier system [1]. However, the anoxic corrosion of the metallic materials is expected due to the changes on the environmental conditions around the buried structures such as resaturation of the repository with time. In this context, corrosion products like iron oxides (i.e. magnetite, $\left.\mathrm{Fe}_{3} \mathrm{O}_{4}\right)$ or hydroxides, and dihydrogen $\left(\mathrm{H}_{2}\right)$ are also expected to be formed according to the following reactions (Eqs. 1-8) [1]:

In aerobic condition

$$
\begin{aligned}
& 4 \mathrm{Fe}+3 \mathrm{O}_{2} \rightarrow 2 \mathrm{Fe}_{2} \mathrm{O}_{3} \\
& 4 \mathrm{Fe}+6 \mathrm{H}_{2} \mathrm{O}+3 \mathrm{O}_{2} \rightarrow 4 \mathrm{Fe}(\mathrm{OH})_{3} \\
& 2 \mathrm{Fe}+\mathrm{H}_{2} \mathrm{O}+3 / 2 \mathrm{O}_{2} \rightarrow 2 \mathrm{FeO}(\mathrm{OH})
\end{aligned}
$$

In anaerobic condition

$$
\begin{aligned}
& 3 \mathrm{Fe}+4 \mathrm{H}_{2} \mathrm{O} \rightarrow \mathrm{Fe}_{3} \mathrm{O}_{4}+4 \mathrm{H}_{2} \\
& \mathrm{Fe}+2 \mathrm{H}_{2} \mathrm{O} \rightarrow \mathrm{Fe}(\mathrm{OH})_{2}+\mathrm{H}_{2} \\
& 3 \mathrm{Fe}(\mathrm{OH})_{2} \rightarrow \mathrm{Fe}_{3} \mathrm{O}_{4}+2 \mathrm{H}_{2} \mathrm{O}+\mathrm{H}_{2}
\end{aligned}
$$

\section{Mineral transformation and phase transition}

$$
\begin{aligned}
& 4 \mathrm{Fe}_{2} \mathrm{O}_{3}+\mathrm{Fe} \rightarrow 3 \mathrm{Fe}_{3} \mathrm{O}_{4} \\
& 2 \mathrm{Fe}(\mathrm{OH})_{3}+4 \mathrm{Fe}+2 \mathrm{H}_{2} \mathrm{O} \rightarrow 2 \mathrm{Fe}_{3} \mathrm{O}_{4}+5 \mathrm{H}_{2}
\end{aligned}
$$

The production of dihydrogen poses two major problems. On the one hand, it represents a significant threat to the repository when accumulated for a long time in the surrounding clay because it may damage the barrier properties of the geological formation, affecting the safety of the repository. On the other hand, dihydrogen also represents a new energy source for microbial growth, especially in such anoxic environments with low content of biodegradable organic matter.

Several studies have already pointed out the possibility of microbiological life in the deep geological disposal [2-5], and both biological activity and biofilm formation may influence the metallic corrosion rate. These phenomena are usually known as microbiologically influenced corrosion (MIC), which can represent a huge problem when promoting local metal dissolution by different mechanisms which vary with the microbial species and chemistry of the colonized metal surface [6]. For instance, in such confined environment, some iron-reducing bacteria (IRB) are able to use simultaneously dihydrogen as electron donor and ferric iron as electron acceptor for their anaerobic respiration [7, 8]. In this study, Shewanella oneidensis was chosen as an IRB and hydrogen-oxidizing bacteria HOB model microorganism. It is a facultative anaerobic bacterium [9] able to use different compounds as electron donor, such as lactate, formate, pyruvate, amino acids and also 
dihydrogen [10]. According to El-Naggar et al. [11] the respiration rate of Shewanella oneidensis strain MR-1 is $2.6 \times 10^{6}$ electrons per cell per second using lactate as electron donor. In addition, some mechanisms of IRB species using electron transfers from solid substrates have already been described in the literature, such as:

- the use of mediators which can act as electron shuttles transferring electrons from the cells to the acceptors compounds [12, 13];

- the direct contact of cells with solid substrate through multihemes cytochromes at the external membrane [14];

- the use of conductive intracellular filaments (i.e. nanowires) [11].

It is well-known that the presence of microorganisms can influence the corrosion rate [6, 15-19], but is not well elucidated if IRB are able to induce local corrosion. The overall influence of microorganism on corrosion mechanism is still under debate since it depends on many factors [6].

Electrochemical techniques such as cyclic voltammetry (CV) and electrochemical impedance spectroscopy (EIS) were already proved to be powerful tools for corrosion investigations. Valuable parameters can be gathered about the kinetics of interfacial processes from the measurements of current or potential. However, these results are obtained as an average behavior of the whole interface, which render difficult the elucidation of the local corrosion mechanisms [20-23]. Therefore, the use of local techniques is needed to describe the interface reactivity.

The objective of this study is to characterize the electrochemical interface by both local and global techniques during biocorrosion of low carbon steel in presence of Shewanella oneidensis used as model of IRB and HOB. Scanning electrochemical microscopy (SECM), which has been widely described by Bard et al. [24-26] and subject of numerous reviews [2729], and local electrochemical impedance spectroscopy pioneered by Isaacs et al. [21, 30] were used as electrochemical techniques. Carbon steel has been considered as candidate material for the multi-barrier system due to the low corrosion rate under reducing conditions. In a previous study [31], corrosion products, iron oxides (e.g. magnetite) and $\mathrm{H}_{2}$ were shown to favor the hydrogen-oxidizing IRB development in the context of active corrosion of metallic radioactive waste containers. Moreover, the size of bacterial cells is in the range of few micrometers to few tens micrometers, which makes possible to perform local electrochemical measurements even in the biofilm environment. A microelectrode can also be used for generating locally $\mathrm{H}_{2}$ in the close vicinity of the bacterial cells.

\section{Experimental}

\subsection{Bacterial culture}

The cultures of Shewanella oneidensis strain MR-1 (ATCC $700550^{\mathrm{TM}}$ ) were obtained aerobically at the beginning of the stationary growth phase in Luria Bertani Broth (LB) medium $\left(5\right.$ g.L $\mathrm{L}^{-1} \mathrm{NaCl}, 10 \mathrm{~g} . \mathrm{L}^{-1}$ tryptone, $5 \mathrm{~g} . \mathrm{L}^{-1}$ yeast extract) after $24 \mathrm{~h}$ at $30^{\circ} \mathrm{C}$. Shewanella oneidensis cells were harvested from the LB medium by centrifugation (4000 rpm for 20 min), washed once with sterile minimal medium (M1) and then inoculated in electrochemical reactor (initial concentration of $10^{8}$ cells. $\mathrm{mL}^{-1}$ counted by THOMA counting chamber). The chemically defined minimal medium (M1) was prepared according to Esnault et al. [31]. The composition consisted in a mixture of $9 \mathrm{mM}\left(\mathrm{NH}_{4}\right)_{2} \mathrm{SO}_{4}, 2 \mathrm{mM} \mathrm{NaHCO} 3,0.8 \mathrm{mM}$ $\mathrm{MgSO}_{4} .7 \mathrm{H}_{2} \mathrm{O}, 0.4 \mathrm{mM} \mathrm{CaCl} 2.2 \mathrm{H}_{2} \mathrm{O}, 45 \mu \mathrm{M} \mathrm{H}_{3} \mathrm{BO}_{3}, 10 \mu \mathrm{M} \mathrm{NaCl}, 4 \mu \mathrm{M} \mathrm{FeSO} 4.7 \mathrm{H}_{2} \mathrm{O}, 5 \mu \mathrm{M}$ $\mathrm{CoSO}_{4} \cdot 7 \mathrm{H}_{2} \mathrm{O}, 5 \mu \mathrm{M} \quad \mathrm{NiSO}_{4} \cdot 6 \mathrm{H}_{2} \mathrm{O}, 3 \mu \mathrm{M} \quad \mathrm{Na}_{2} \mathrm{MoO}_{4} \cdot 2 \mathrm{H}_{2} \mathrm{O}, 11 \mu \mathrm{M} \quad \mathrm{Na}_{2} \mathrm{SeO}_{4}, 1 \mu \mathrm{M}$ $\mathrm{MnSO}_{4} . \mathrm{H}_{2} \mathrm{O}, 0.8 \mu \mathrm{M} \mathrm{ZnSO}_{4} .7 \mathrm{H}_{2} \mathrm{O}, 0.2 \mu \mathrm{M} \mathrm{CuSO}_{4} .5 \mathrm{H}_{2} \mathrm{O}, 17 \mathrm{mM}$ HEPES buffer, amino acids (0.11 $\mathrm{mM}$ arginine, $0.13 \mathrm{mM}$ glutamate, $0.19 \mathrm{mM}$ serine $)$, and vitamins (0.08 $\mathrm{mM}$ nicotinic 
acid, $0.01 \mathrm{mM}$ thiamine- $\mathrm{HCl}, 0.40 \mu \mathrm{M}$ biotine). The $\mathrm{pH}$ was adjusted to ca. 7 with $\mathrm{NaOH}$ and then the medium was sterilized by autoclaving $\left(120^{\circ} \mathrm{C}\right.$ for $\left.20 \mathrm{~min}\right)$, except for the thermolabile components (e.g. amino acids) which were filter-sterilized $(0.22 \mu \mathrm{m})$. For local impedances experiments this medium was prepared without phosphate ions in its composition.

\subsection{Carbon steel coupons}

Low carbon steel coupons A37 (0.12\% C, 0.22\% Si, 0.62\% Mn, 0.008\% Al, $0.012 \% \mathrm{~S}$ and $\mathrm{P}, 0.02 \% \mathrm{Ni}, 0.03 \% \mathrm{Cr}, 0.04 \% \mathrm{Cu}, 0.005 \% \mathrm{Co}$ and $<0.005 \% \mathrm{Ti}$ ) were obtained from the CEA (Commissariat à l'Energie Atomique et aux Energies Alternatives - France). Rod-shaped coupons (1 cm in diameter) were laterally insulated with a cathaphoretic paint and then molded in a diallylphthalate glass-fiber resin (Presi), leaving a disk area of $0.79 \mathrm{~cm}^{2}$ exposed to the solution. Prior to each experiment, the electrode was polished with emery paper (P600 grit $\mathrm{SiC}$ ) and sterilized with ethanol by sonication for $15 \mathrm{~min}$.

\subsection{Electrochemical experiments}

\subsubsection{Scanning electrochemical microscopy (SECM)}

Preliminary experiments for the detection of $\mathrm{H}_{2}$ were performed in a $0.5 \mathrm{M}$ sulfuric acid solution with a platinum electrode of $0.5 \mathrm{~cm}$ in diameter as substrate and a platinum microelectrode of $20 \mu \mathrm{m}$ in radius.

For the experiments related to the study of carbon steel corrosion, the electrochemical measurements were performed with a home-made scanning electrochemical microscope (SECM), which consisted in a 4-electrode cell configuration depicted in Scheme 1, elaborated specifically for anaerobic and sterile conditions. A double-wall glass cell thermostated at $30^{\circ} \mathrm{C}$ allowed the carbon steel working electrode (WE1) to be placed in the bottom of the cell in a face up position. The reference and the counter electrodes consisted in a saturated calomel reference electrode (SCE) and a platinum gauze, respectively. The cell was closed with a Teflon cover where a flexible nitrile bracket was adapted. Throughout this flexible support, a platinum tip of $50 \mu \mathrm{m}$ in diameter, acting as a second mobile working electrode for generating $\mathrm{H}_{2}$ in solution (see Results and discussion section), was placed perpendicular to WE1. A home-made bi-potentiostatic workstation coupled with high gain and low noise current to voltage converters were used. The microelectrode was positioned with the help of motorized stages allowing a spatial resolution of $200 \mathrm{~nm}$ along the 3-axis and was driven by a motion controller (Newport). All experiments were computer controlled with a Labview software [32, 33]. The disassembled cell and the electrodes were sterilized prior to experiments with $70 \%$ ethanol solution for $20 \mathrm{~min}$; and then rinsed with sterilized water in laminar flow chamber followed by UV irradiation for $15 \mathrm{~min}$. Whenever possible, the instrumentation was sterilized in an autoclave. The cell was assembled under sterile conditions and $260 \mathrm{~mL}$ of M1 medium was introduced and deaerated for $2 \mathrm{~h}$ under $\mathrm{N}_{2}$ atmosphere. The $\mathrm{N}_{2}$ flow was maintained at the headspace of the cell (near to the liquid surface) so as to ensure the anaerobic conditions during the whole duration of the electrochemical measurements.

The contact point between the substrate and the probe (i.e. the distance 0) was determined by performing an approach curve [24, 34]. Then, the SECM was used in generation / collection mode [35, 36] for investigating the role of $\mathrm{H}_{2}$ for different distances between the probe and substrate.

Here Scheme 1 


\subsubsection{Local electrochemical impedance spectroscopy (LEIS)}

Similarly to the SECM, LEIS consisted in using a micro probe for measuring the local current density [21, 37-39]. The two devices require some similar apparatus, in particular for positioning the probe in the vicinity of the substrate. The LEIS is based on the measurement of the local potential difference in solution with a bi microreference electrode (dual $\mathrm{Ag} / \mathrm{AgCl}$ microelectrodes) positioned close to the substrate as sketched in Scheme 2. These microreference electrodes were obtained from the anodization of silver microelectrodes in a potassium chloride solution. The local AC-current density $i_{l o c}(\omega)$ was obtained through the Ohm's law using [40]:

$$
i_{\text {loc }}(\omega)=\frac{\Delta V_{\text {probe }}(\omega) \kappa}{d}
$$

where $\kappa$ is the electrolyte conductivity, $\Delta V_{\text {probe }}(\omega)$ is the AC potential difference between the two probes, and $d$ is the distance between the two probes. The local impedance $(z)$ involves the electrode potential measured with respect to a reference electrode located far from the electrode surface and the local current according to [38-40]:

$$
z(\omega)=\frac{\tilde{V}(\omega)-\Phi_{\text {ref }}}{i_{\text {loc }}(\omega)}=\frac{\tilde{V}(\omega)}{\Delta V_{\text {probe }}(\omega)} \frac{d}{\kappa}
$$

where $\tilde{V}(\omega)-\Phi_{\text {ref }}$ represents the AC potential difference between the electrode surface and the reference electrode in the bulk solution. Similarly to other scanning probe techniques, the spatial resolution of the LEIS is governed by the size of the probe and the distance between the probe and the steel substrate. The measurements were carried out with a four-channel frequency response analyzer (Solartron 1254) and the potential difference between the two microelectrodes was amplified with a home-made differential amplifier. For this study, a specific tri-microelectrode was devised (Scheme 2) allowing the generation of $\mathrm{H}_{2}$ and local microbiological activity to be induced with the platinum microelectrode (similarly to the generation / collection mode of the SECM), and the simultaneous local electrochemical impedance measurement with the two $\mathrm{Ag} / \mathrm{AgCl}$ microreference electrodes.

\section{Here Scheme 2}

\subsection{Characterization of the coupon surface}

Steel coupon surfaces were analyzed at the end of the experiments by scanning electron microscopy (SEM). These investigations were performed with a Leica Stereoscan 440 microscope coupled with EDS elemental semi-quantitative analyses (Princeton Gamma$\mathrm{Tech})$ at $20 \mathrm{keV}$ and $5.3 \mathrm{nA}$. The samples were slightly rinsed with deionised water, dried with $\mathrm{N}_{2}$ gas and stored in plastic containers until analysis. The coupons were coated with carbon prior to SEM analysis.

\section{Results and discussions}


The results of the preliminary experiments related to the generation / collection of $\mathrm{H}_{2}$ in solution are illustrated in the Figure 1. These experiments were performed in a $0.5 \mathrm{M}$ sulfuric acid solution with a $0.5 \mathrm{~cm}$ in diameter platinum electrode as substrate. The potential of the substrate was swept at $15 \mathrm{mVs}^{-1}$ in the $\mathrm{H}_{2}$ evolution reaction domain (Fig. 1a), whereas the dissolved $\mathrm{H}_{2}$ generated by the substrate was simultaneously monitored as a function of time with a platinum microelectrode biased at $0.3 \mathrm{~V}$ (vs. SCE) for different tip-to-substrate distance (Figure 1b). The current peak observed after about 11 seconds corresponds to the beginning of the reverse scan of the Pt substrate. It is noteworthy that the current of the substrate does not depend on the tip-to-substrate distance (Figure 1a). Conversely, the response of the probe strongly depends on this distance. First, there is a further delay in the response of the probe, which corresponds to a longer time for the electrogenerated species to reach the microelectrode when it is positioned far from the substrate. Second, due to the concentration gradient of these species from the Pt substrate to the bulk solution, the peak intensity of the current recorded at the microelectrode decreases with the distance. However, these experiments clearly evidence the possibility of dosing $\mathrm{H}_{2}$ dissolved in solution with a microelectrode positioned at a distance smaller than few microelectrode radii.

Here Fig. 1

Figure 2 shows the $\mathrm{CV}$ curves of a platinum probe at $15 \mathrm{mVs}^{-1}$ positioned at $80 \mu \mathrm{m}$ of the interface in abiotic (blue curve) and biotic (red curve) conditions for $72 \mathrm{~h}$ and $24 \mathrm{~h}$ after inoculation, respectively. These two curves were obtained successively during the same experiment and at the same location for the probe. During the cathodic scan, $\mathrm{H}_{2}$ is generated at the probe and diffuses towards the interface where it can be consumed by the bacteria. The anodic scan corresponds to the re-oxidation of $\mathrm{H}_{2}$ remaining in solution. It is noteworthy that the electrochemical cell formed by the microelectrode and the substrate is a thin layer in that case. This is the reason why the anodic peaks observed for both cases are ascribed to the dihydrogen oxidation. Moreover, the amount of $\mathrm{H}_{2}$ determined from the peak area is larger in abiotic conditions, indicating a consumption of $\mathrm{H}_{2}$ by the bacteria.

\section{Here Fig. 2}

This result is confirmed by Figure 3 on which the exchanged charge for different microelectrode-to-substrate distances is reported for biotic (red curve) and abiotic (blue curve) conditions. Interestingly, the two curves exhibit very similar behavior and the difference between the two curves provides an evaluation of the $\mathrm{H}_{2}$ consumption by the bacteria. A mean value of about $0.12 \mu \mathrm{C}$ was obtained for the amount of $\mathrm{H}_{2}$ consumed. From the Faraday's law, this corresponds to about $610^{-13} \mathrm{~mol}$ of $\mathrm{H}_{2}$, and taking into account the duration of the $\mathrm{CV}$ experiment for both generation and dosing of $\mathrm{H}_{2}$, this correspond to a $\mathrm{H}_{2}$ consumption rate of about $10^{-14} \mathrm{mols}^{-1}$ for biotic conditions. For comparison, the charge exchanged during the $\mathrm{H}_{2}$ production by the tip was about $9 \mu \mathrm{C}$ showing that only 1 to $1.5 \%$ of the $\mathrm{H}_{2}$ generated is involved in the bacterial activity.

\section{Here Fig. 3}

Figure 4 shows the global impedance diagrams of the steel coupon for biotic conditions. These experiments were performed with $\mathrm{H}_{2}$ generation by the probe polarized at $-1 \mathrm{~V} / \mathrm{ECS}$ and generating a dc current of about $50 \mathrm{nA}$, as shown in the experimental setup of the Scheme 2. The high frequency loop between $65 \mathrm{kHz}$ and $10 \mathrm{kHz}$ is ascribed to artefacts as already described in the literature [41], and the electrochemical system can be readily described with two time constants. The high frequency time constant $(10 \mathrm{kHz}<\mathrm{f}<100 \mathrm{~Hz})$ is characterized by an amplitude of about $30 \Omega \mathrm{cm}^{2}$ and does not significantly varies with time. Such value is small and cannot be attributed to a charge transfer resistance, but to a thin corrosion layer products which have already been described for carbon steel in sterile artificial 
sea water [42]. In addition, the analysis of this flattened capacitive loop allows a constant phase element to be determined, and from the used of Brug formula [43, 44], a capacitance is obtained (Figure 5). This capacitance is about $7 \mu \mathrm{Fcm}^{-2}$ and is time independent. Assuming a permittivity of 10 for the corrosion products, the thickness of the layer is in the range of 1 to 2 nm. As shown in Figure 4, in the low frequency domain $(\mathrm{f}<100 \mathrm{~Hz})$, a second time constant can also be evidenced. The amplitude of the loop is independent of the duration of the experiment (3000 $\Omega \mathrm{cm}^{2}$ ) and is ascribed to the charge transfer resistance of the steel dissolution process. The fitting of this low frequency time constant also needs the use of a constant phase element (CPE), and as previously mentioned, the use of Brug formula allows the double layer capacitance to be obtained. Its variations are reported in Figure 6 and show an increase with time after 60 hours (whereas in abiotic condition, a continuous increase with time was obtained) from $300 \mu \mathrm{Fcm}^{-2}$ to $750 \mu \mathrm{Fcm}^{-2}$ after five days. Such unusual high values for double layer capacitance can be explained by the accumulation of corrosion product over the electrode surface and the 3D architecture of the interface in presence of biological material $[42,45]$. Thus, the constant value of the charge transfer resistance indicates that the carbon steel is dissolving at a constant rate, whereas the increase of the double layer capacitance is linked to the growth of the system formed by the bacteria and the corrosion products.

\section{Here Fig. 4 \\ Here Fig. 5 \\ Here Fig. 6}

During the same set of experiments, local impedance measurements were performed on various locations above the steel substrate. Figure 7 shows some examples of LEIS diagrams obtained at the electrode center (Figure 7a) and at $1 \mathrm{~mm}$ from the center (Figure $7 \mathrm{~b}$ ). Both set of diagrams are very similar. In the high frequency domain, the inductive behavior is due to the cell geometry, as already described by Frateur et al. [37, 46]. This inductive component hides the first capacitive loop, and only the second loop corresponding to the charge transfer can be used for the fitting. Interestingly, the values of the charge transfer resistance are independent of both time and location. This indicates that from a local point of view (the spatial resolution of the setup used is about $100 \mu \mathrm{m}$ ) the reactivity of the interface does not depend on the position. In addition, the double layer capacitance obtained from local measurements shows the same trends with time (i.e. a continuous increase), but this value remains constant for various location at different times. This is in agreement with the charge transfer resistance variation and suggests that Shewanella oneidensis influences the overall reaction rate in this environment, but no local corrosion could have been evidenced from the analysis of electrochemical results. In addition, this was supported by post-mortem SEM observations as shown in Figure 8. The visual appearance of steel is characteristic of a generalized corrosion and a close examination of the surface after different experiments never allowed evidencing localized corrosion.

Here Fig. 7

Here Fig. 8

\section{Conclusions}

This work shows that local electrochemical techniques are applicable for the investigation of biocorrosion using Shewanella oneidensis as model of iron-reducing bacteria as well as hydrogen-oxidizing bacteria. The dissolved $\mathrm{H}_{2}$ concentration in $\mathrm{H}_{2} \mathrm{SO}_{4}$ solution can 
be measured or controlled by SECM with the generation / collection mode when the distance between the tip and the substrate is smaller than few microelectrode radii. The charge of the $\mathrm{H}_{2}$ re-oxidation, in the thin layer between the probe and the substrate, was compared for biotic and abiotic conditions. A small charge was observed for biotic conditions indicating that an amount of the $\mathrm{H}_{2}$ generated by the probe was consumed by Shewanella oneidensis. Therefore, the use of the scanning electrochemical microscopy allowed evidencing the $\mathrm{H}_{2}$ consumption by the bacteria. Moreover, a $\mathrm{H}_{2}$ consumption rate of about $10^{-14} \mathrm{~mol} \mathrm{~s}^{-1}$ was measured when only corrosion products were used as energetic substrates.

Two capacitive loops were observed in the global impedance measurements from the experiments performed with the M1 medium for biotic conditions. The high frequency loop can be attributed to a thin layer of corrosion products due to the small and constant values of capacitance $\left(9.5 \mu \mathrm{Fcm}^{-2}\right)$. A thickness in the range of 1 to $2 \mathrm{~nm}$ was estimated for this layer. The charge transfer resistance of the steel dissolution process was attributed to the low frequency range. The high capacitance values measured are caused by the spatial distribution of species in the biofilm in combination with growth of a film of corrosion products. General corrosion was clearly evidenced by local electrochemical results and SEM observations. Thus, starting from the general idea that biocorrosion is associated to localized corrosion; this work clearly shows that in the case of Shewanella oneidensis, generalized corrosion predominates for short-time experiments.

These local descriptions of electrochemical processes offer new perspectives for investigating the relevant activity of a given microorganism, or to studying the concomitant effect of actual environment in combination to the presence of bacteria.

\section{Acknowledgements}

This research was funded by the European Community's Seventh Framework Programme (FP7/2007-2013) by the BIOCOR project. The authors wish to thank Damien Féron (CEA Saclay, France) for carbon steel samples and Françoise Pillier (LISE, UPR15, France) for SEM analysis. 


\section{References}

[1] D. David, Analogue archéologique et corrosion, Collection Sciences et Techniques, in: Andra scientific report, Bio Intelligence Service, Paris, 2005, 1-76.

[2] S. Stroes-Gascoyne, Microbial occurrence in bentonite-based buffer, backfill and sealing materials from large-scale experiments at AECL's Underground Research Laboratory, Appl. Clay Sci., 47 (2010) 36-42.

[3] K. Pedersen, Investigations of subterranean bacteria in deep crystalline bedrock and their importance for the disposal of nuclear waste, Can. J. Microbiol., 42 (1996) 382-391.

[4] S. Stroes-Gascoyne, C.J. Hamon, D.A. Dixon, J.B. Martino, Microbial analysis of samples from the tunnel sealing experiment at AECL's Underground Research Laboratory, Phys Chem Earth, 32 (2007) 219-231.

[5] L. Urios, F. Marsal, D. Pellegrini, M. Magot, Microbial diversity of the 180 million-yearold Toarcian argillite from Tournemire, France, Appl Geochem, 27 (2012) 1442-1450.

[6] W.B. Beech, J. Sunner, Biocorrosion: towards understanding interactions between biofilms and metals, Curr. Opin. Biotechnol., 15 (2004) 181-186.

[7] D.R. Lovley, D.E. Holmes, K.P. Nevin, Dissimilatory Fe(III) and Mn(IV) reduction, in: Advances in Microbial Physiology, Vol. 49, 2004, 219-286.

[8] M. Libert, O. Bildstein, L. Esnault, M. Jullien, R. Sellier, Molecular hydrogen: An abundant energy source for bacterial activity in nuclear waste repositories, Phys Chem Earth, 36 (2011) 1616-1623.

[9] T. Perez-Gonzalez, C. Jimenez-Lopez, A.L. Neal, F. Rull-Perez, A. Rodriguez-Navarro, A. Fernandez-Vivas, E. Ianez-Pareja, Magnetite biomineralization induced by Shewanella oneidensis, Geochim. Cosmochim. Acta, 74 (2010) 967-979.

[10] K.H. Nealson, A. Belz, B. McKee, Breathing metals as a way of life: geobiology in action, Antonie Van Leeuwenhoek, Anton Leeuw Int J G, 81 (2002) 215-222.

[11] M.Y. El-Naggar, G. Wanger, K.M. Leung, T.D. Yuzvinsky, G. Southam, J. Yang, W.M. Lau, K.H. Nealson, Y.A. Gorby, Electrical transport along bacterial nanowires from Shewanella oneidensis MR-1, Proc. Natl. Acad. Sci. U.S.A., 107 (2010) 18127-18131.

[12] E.D. Brutinel, J.A. Gralnick, Shuttling happens: soluble flavin mediators of extracellular electron transfer in Shewanella, Appl. Microbiol. Biotechnol., 93 (2012) 41-48.

[13] D.R. Lovley, Microbial fuel cells: novel microbial physiologies and engineering approaches, Curr. Opin. Biotechnol., 17 (2006) 327-332.

[14] Z.W. Du, H.R. Li, T.Y. Gu, A state of the art review on microbial fuel cells: A promising technology for wastewater treatment and bioenergy, Biotechnol. Adv., 25 (2007) 464-482.

[15] D.A. Jones, P.S. Amy, A thermodynamic interpretation of microbiologically influenced corrosion, Corrosion, 58 (2002) 638-645.

[16] J.P. Busalmen, M. Vazquez, S.R. de Sanchez, New evidences on the catalase mechanism of microbial corrosion, Electrochim. Acta, 47 (2002) 1857-1865.

[17] G.D. Schrott, P.S. Bonanni, L. Robuschi, A. Esteve-Nunez, J.P. Busalmen, Electrochemical insight into the mechanism of electron transport in biofilms of Geobacter sulfurreducens, Electrochim. Acta, 56 (2011) 10791-10795.

[18] S. Da Silva, R. Basseguy, A. Bergel, Electron transfer between hydrogenase and 316L stainless steel: identification of a hydrogenase-catalyzed cathodic reaction in anaerobic mic, $\mathrm{J}$ Electroanal Chem, 561 (2004) 93-102.

[19] I.B. Beech, S.A. Campbell, Accelerated low water corrosion of carbon steel in the presence of a biofilm harbouring sulphate-reducing and sulphur-oxidising bacteria recovered from a marine sediment, Electrochim. Acta, 54 (2008) 14-21.

[20] H.S. Isaacs, The localized breakdown and repair of passive surfaces during pitting, Corros.Sci., 29 (1989) 313-323. 
[21] R.S. Lillard, P.J. Moran, H.S. Isaacs, A novel method for generating quantitative local electrochemical impedance spectroscopy, J Electrochem Soc, 139 (1992) 1007-1012.

[22] G. Galicia, N. Pebere, B. Tribollet, V. Vivier, Corrosion study of an AZ91 magnesium alloy by EIS and LEIS, ECS Transactions, 1 (2006) 157-168.

[23] K.S. de Assis, F.V.V. de Sousa, M. Miranda, I.C.P. Margarit-Mattos, V. Vivier, O.R. Mattos, Assessment of electrochemical methods used on corrosion of superduplex stainless steel, Corros. Sci., 59 (2012) 71-80.

[24] A.J. Bard, F.R.F. Fan, J. Kwak, O. Lev, Scanning electrochemical microscopy. Introduction and principles, Anal. Chem., 61 (1989) 132-138.

[25] C. Lee, J. Kwak, A.J. Bard, Application of scanning electrochemical microscopy to biological samples, Proc. Natl. Acad. Sci. U.S.A., 87 (1990) 1740-1743.

[26] A.J. Bard, F.R.F. Fan, D.T. Pierce, P.R. Unwin, D.O. Wipf, F. Zhou, Chemical imaging of surfaces with the scanning electrochemical microscope, Science, 254 (1991) 68-74.

[27] M.V. Mirkin, W. Nogala, J. Velmurugan, Y. Wang, Scanning electrochemical microscopy in the 21st century. Update 1: five years after, Phys. Chem. Chem. Phys., 13 (2011) 21196-21212.

[28] M. Keddam, N. Portail, D. Trinh, V. Vivier, Progress in Scanning Electrochemical Microscopy by Coupling with Electrochemical Impedance and Quartz Crystal Microbalance, ChemPhysChem, 10 (2009) 3175-3182.

[29] G. Wittstock, M. Burchardt, S.E. Pust, Y. Shen, C. Zhao, Scanning electrochemical microscopy for direct imaging of reaction rates, Angew. Chem. Int. Ed. Engl., 46 (2007) 1584-1617.

[30] F. Zou, D. Thierry, H.S. Isaacs, A high-resolution probe for localized electrochemical impedance spectroscopy measurements, J Electrochem Soc, 144 (1997) 1957-1965.

[31] L. Esnault, M. Jullien, C. Mustin, O. Bildstein, M. Libert, Metallic corrosion processes reactivation sustained by iron-reducing bacteria: Implication on long-term stability of protective layers, Phys Chem Earth, 36 (2011) 1624-1629.

[32] C. Gabrielli, M. Keddam, N. Portail, P. Rousseau, H. Takenouti, V. Vivier, Electrochemical Impedance Spectroscopy Investigations of a Microelectrode Behavior in a Thin-Layer Cell: Experimental and Theoretical Studies, J Phys Chem B, 110 (2006) 2047820485.

[33] C. Gabrielli, F. Huet, M. Keddam, P. Rousseau, V. Vivier, Scanning Electrochemical Microscopy Imaging by Means of High-Frequency Impedance Measurements in Feedback Mode, J Phys Chem B, 108 (2004) 11620-11626.

[34] J. Kwak, A.J. Bard, Scanning electrochemicam microscopy. Theory of the feedback mode, Anal. Chem., 61 (1989) 1221-1227.

[35] G. Wittstock, Imaging localized reactivities of surfaces by scanning electrochemical microscopy, Topics in Applied Physics, 85 (2003) 335-364.

[36] C.M. Sanchez-Sanchez, J. Rodriguez-Lopez, A.J. Bard, Scanning Electrochemical Microscopy. 60. Quantitative Calibration of the SECM Substrate Generation/Tip Collection Mode and Its Use for the Study of the Oxygen Reduction Mechanism, Anal. Chem., 80 (2008) 3254-3260.

[37] I. Frateur, V.M. Huang, M.E. Orazem, B. Tribollet, V. Vivier, Experimental Issues Associated with Measurement of Local Electrochemical Impedance, J Electrochem Soc, 154 (2007) C719-C727.

[38] V.M.-W. Huang, V. Vivier, M.E. Orazem, N. Pebere, B. Tribollet, The apparent constant-phase-element behavior of an ideally polarized blocking electrode a global and local impedance analysis, J Electrochem Soc, 154 (2007) C81-C88. 
[39] V.M. Huang, S.-L. Wu, M.E. Orazem, N. Pebere, B. Tribollet, V. Vivier, Local electrochemical impedance spectroscopy: A review and some recent developments, Electrochim. Acta, 56 (2011) 8048-8057.

[40] H.S. Isaacs, The effect of height on the current distribution measured with a vibrating electrode probe, J Electrochem Soc, 138 (1991) 722-728.

[41] A.T. Tran, F. Huet, K. Ngo, P. Rousseau, Artefacts in electrochemical impedance measurement in electrolytic solutions due to the reference electrode, Electrochim. Acta, 56 (2011) 8034-8039.

[42] H. Castaneda, X.D. Benetton, SRB-biofilm influence in active corrosion sites formed at the steel-electrolyte interface when exposed to artificial seawater conditions, Corros. Sci., 50 (2008) 1169-1183.

[43] G.J. Brug, A.L.G. van den Eeden, M. Sluyters-Rehbach, J.H. Sluyters, The analysis of electrode impedances complicated by the presence of a constant phase element, J Electroanal Chem, 176 (1984) 275-295.

[44] B. Hirschorn, M.E. Orazem, B. Tribollet, V. Vivier, I. Frateur, M. Musiani, Determination of effective capacitance and film thickness from constant-phase-element parameters, Electrochim. Acta, 55 (2010) 6218-6227.

[45] L.V. Nielsen, L.R. Hilbert, Microbial corrosion of carbon steel by sulfate-reducing bacteria: electrochemical and mechanistic approach, Eur. Fed. Corros. Publ., 22 (1997) 11-24. [46] I. Frateur, V.M.-W. Huang, M.E. Orazem, N. Pebere, B. Tribollet, V. Vivier, Local electrochemical impedance spectroscopy: Considerations about the cell geometry, Electrochim. Acta, 53 (2008) 7386-7395. 


\section{Figure captions}

Scheme 1: Sketch of the SECM setup used in this study.

Scheme 2: Sketch of the LEIS setup used in this study.

Figure 1: Dihydrogen detection with the SECM in $\mathrm{H}_{2} \mathrm{SO}_{4}$ solution. The potential of the Pt substrate was swept in the hydrogen reduction reaction domain at $15 \mathrm{mVs}^{-1}$ (curve a), whereas the platinum probe was biased at $0.3 \mathrm{~V}$ (vs. SCE) for dissolved dihydrogen detection (curve b), with the tip-to-substrate distance as a parameter. The minimum in current observed after 11 seconds on curves of Figure (a) corresponds to the inversion of the potential scan direction.

Figure 2: Cyclic voltammograms of a Pt microelectrode of $50 \mu \mathrm{m}$ in diameter at $15 \mathrm{mVs}^{-1}$ positioned at $80 \mu \mathrm{m}$ from the steel substrate in abiotic (curve a) and biotic (curve b) conditions for $72 h$ and $24 h$ after inoculation, respectively. The curves presented are a zoom of the anodic domain.

Figure 3: Evolution of the amount of $\mathrm{H}_{2}$ oxidized (given as charge) at the Pt microelectrode during the backward scan of potentials as a function of the tip-to-substrate distance. The red curve was measured in abiotic conditions and the blue one in biotic conditions. Symbols are experimental measurements.

Figure 4: Evolution of the global electrochemical impedance diagrams at the corrosion potential in presence of bacteria with time as parameter. Electrode surface $A=0.79 \mathrm{~cm}^{2}$.

- before inoculation; $\bullet$ after $4 \mathrm{~h} ; \Delta$ after $44 \mathrm{~h} ; \boldsymbol{\nabla}$ after $68 \mathrm{~h} ;>$ after $93 \mathrm{~h} ;<$ after $116 \mathrm{~h}$

Figure 5: Evolution of the capacitance in high frequency range.

Figure 6: Evolution of the capacitance in low frequency range.

Figure 7: Evolution of the local electrochemical impedance diagrams in presence of bacteria with time as parameter. (a) at the electrode centre, and (b) at $1 \mathrm{~mm}$ from the electrode centre.

Electrode surface $A=0.79 \mathrm{~cm}^{2}$. $\bigcirc$ before inoculation; $\triangle$ after $1 \mathrm{~h} ; \nabla$ after $4 \mathrm{~h} ; \diamond$ after $44 \mathrm{~h}$;

after 68h; after $93 \mathrm{~h}$; is after $116 \mathrm{~h}$

Figure 8: SEM image of the carbon steel substrate after 5 days of immersion in the M1 solution in biotic conditions. 


\section{Author CVs}

Rebeca Moreira is graduated in Food Engineering with a Master degree in Quality Control in Food and Drink Industries in Rio de Janeiro, Brazil. Started the PhD study in 2010 as a member of the BIOCOR Program at the Laboratory of Interfaces and Systems Electrochemistry (University Pierre et Marie Curie), Paris, France. The subject of her work is the study of the biocorrosion of carbon steel using local electrochemical techniques.

Marta Kerber Schütz received a BS degree in Industrial Chemistry from Catholic University of Rio Grande do Sul, Porto Alegre, Brazil in 2007; completed her MSc in Materials Science and Engineering in March 2010 at the same University. Now she is a PhD student at the French Commission for Atomic Energy and Alternative Energies (CEA). She is working on biocorrosion phenomena implicated on the radioactive waste geological disposal. The overall objective of her study is to better understand the impact of bacterial activities on the corrosion products (specially hydrogen and iron (hydr)oxides) and on the rate of anoxic corrosion.

Marie Libert received her PhD in biochemistry (1986) from the University of CompiegneFrance. She is a senior research engineer at the French Commission for Atomic Energy and Alternative Energies (CEA) since 1998. Her previous affiliation includes a doctoral fellowship at the same university. Her research focuses on different fields such as the effect of microorganisms on long term behaviour of materials used in nuclear repository, biocorrosion, impact of radioactive emission on biota, anaerobic microbiology. She was and she is an european expert on several international research program.

Bernard Tribollet after his graduation from the "Ecole Supérieure d'Electricité" (1973), joined the laboratory of I. Epelboin (now LISE-CNRS UPR 15) where he prepared a PhD under his supervision. In 1981, with the support of a NSF fellowship, he spent one year as visiting scientist at the University of California, Berkeley under the supervision of Prof. John Newman. His current research field concerns different problems: mass transport, electrodissolution, corrosion and in particular biocorrosion. He co-authored, with Prof. Mark Orazem of the University of Florida, a textbook on impedance spectroscopy published in 2008 as part of the Electrochemical Society Series (Wiley).

Vincent Vivier was born in Saint-Maur (France) in 1971. He received his PhD in 2000 under the supervision of Dr. L.T. Yu in Thiais (France). In 2002, he joined the Laboratoire Interfaces et Systèmes Électrochimiques (CNRS - UPR 15). His current research field concerns the characterization of heterogeneous interface reactivity by means of local electrochemical techniques and electrochemical impedance spectroscopy. 
Scheme 1: Sketch of the SECM setup used in this study.

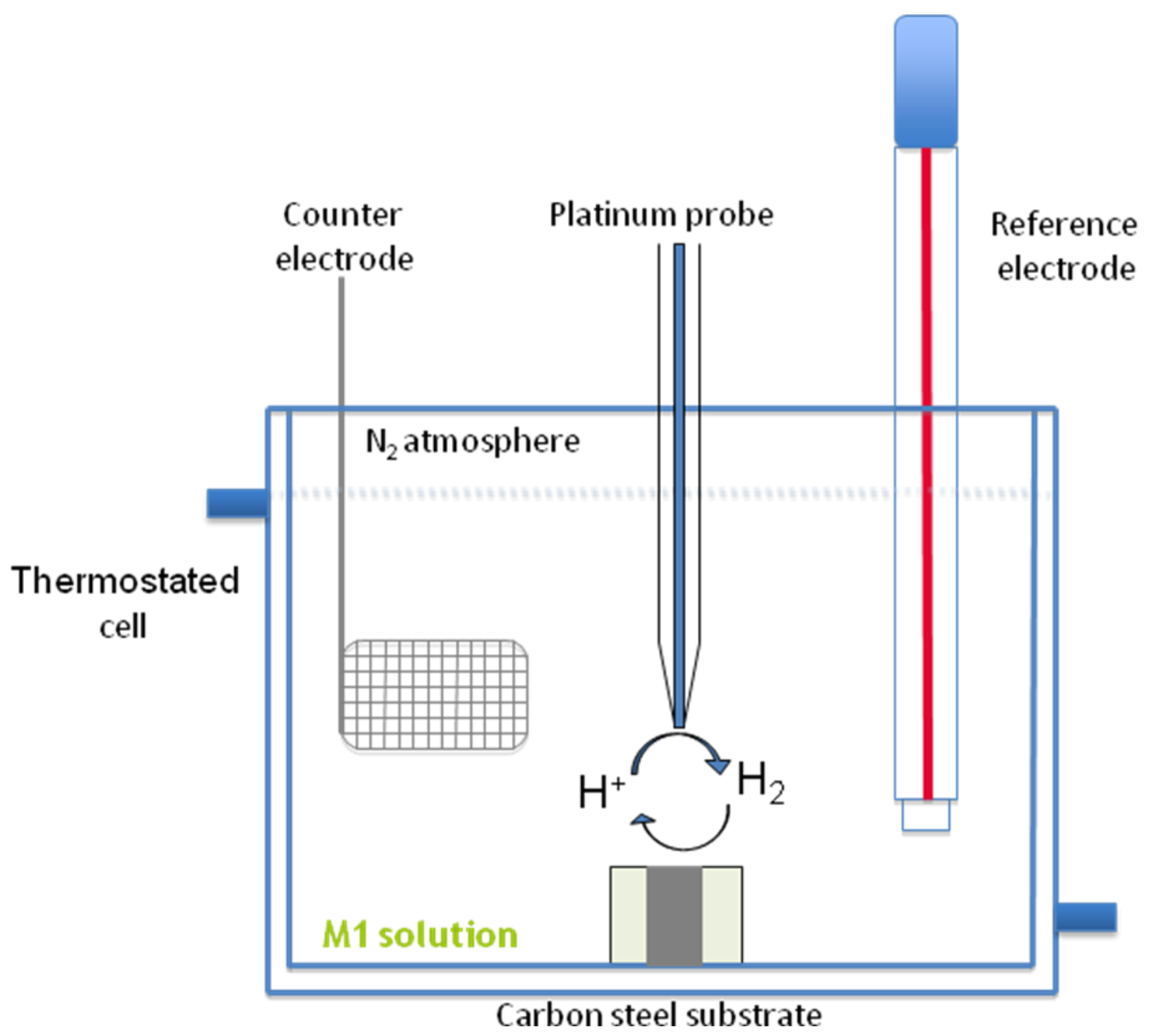


Scheme 2: Sketch of the LEIS setup used in this study.

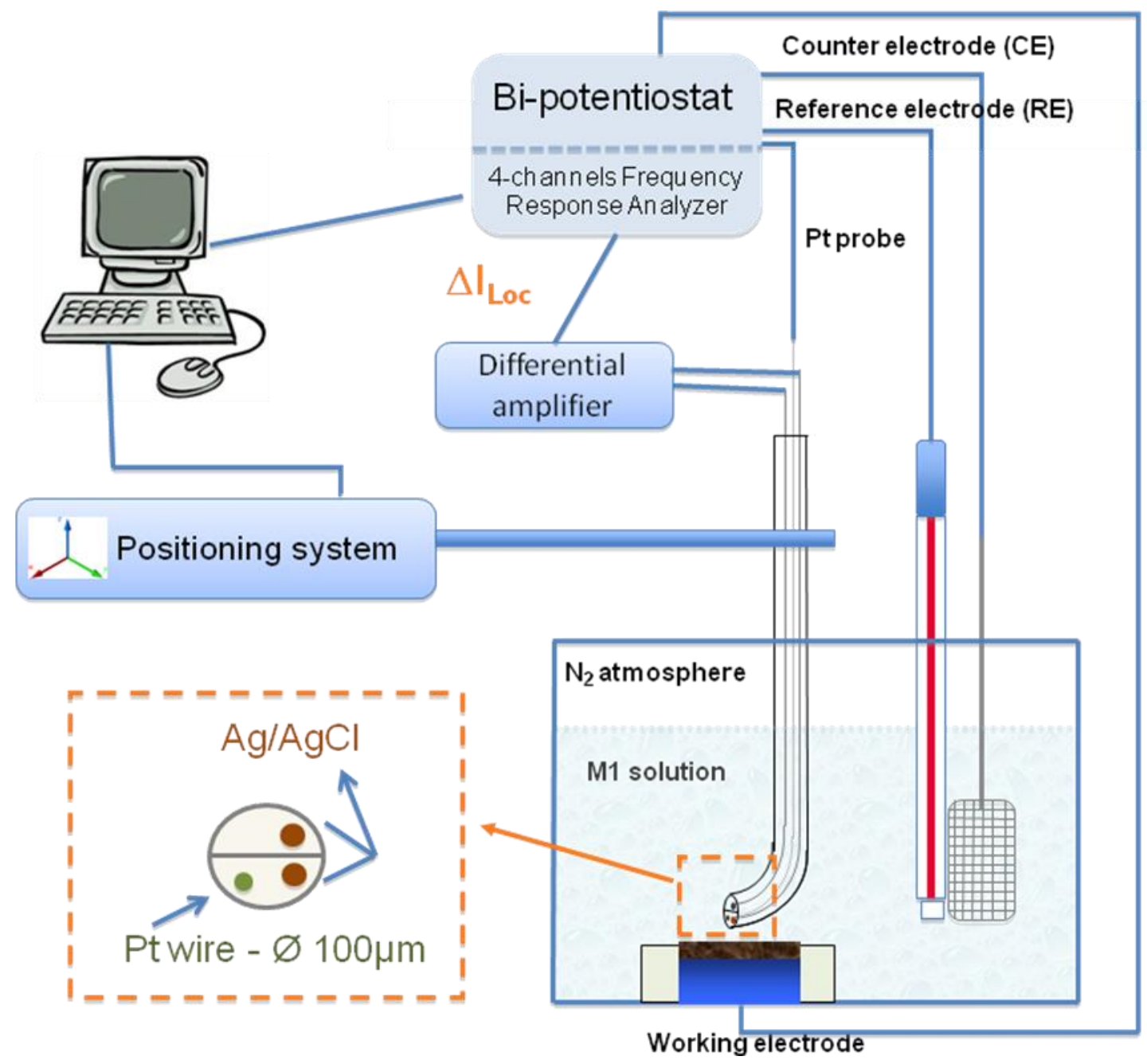


Figure 1: Dihydrogen detection with the SECM in $\mathrm{H}_{2} \mathrm{SO}_{4}$ solution. The potential of the Pt substrate was swept in the hydrogen reduction reaction domain at $15 \mathrm{mVs}^{-1}$ (curve a), whereas the platinum probe was biased at $0.3 \mathrm{~V}$ (vs. SCE) for dissolved dihydrogen detection (curve $b$ ), with the tip-to-substrate distance, $d$, as a parameter. The minimum in current observed at 11 seconds on curves of Figure (a) corresponds to the inversion of the potential scan direction. $1-d=5 \mu \mathrm{m} ; 2-d=10 \mu \mathrm{m} ; 3-d=25 \mu \mathrm{m} ; 4-d=50 \mu \mathrm{m} ; 5-d=100 \mu \mathrm{m} ; 6-d=250 \mu \mathrm{m}$.

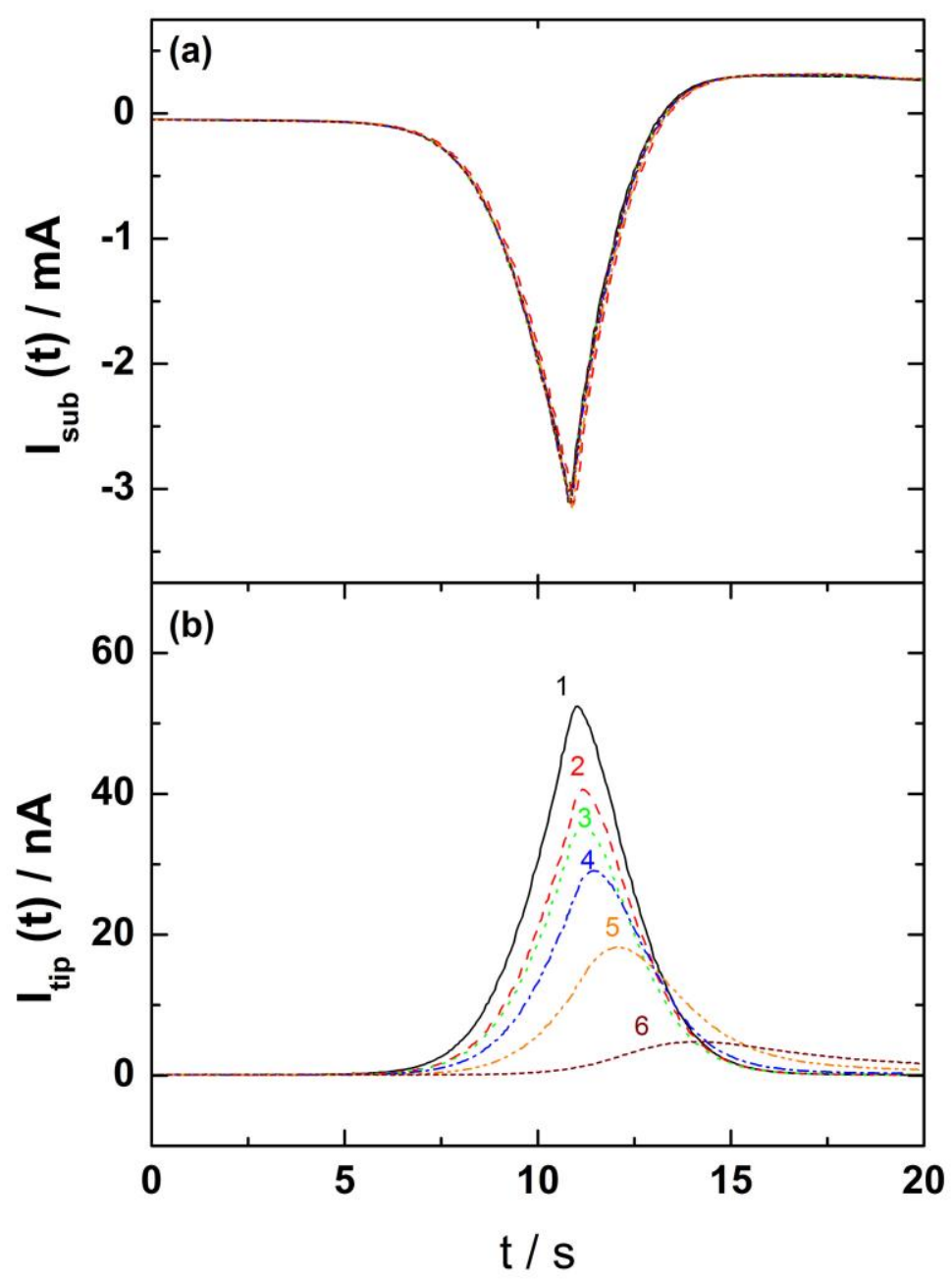


Figure 2: Cyclic voltammograms of a Pt microelectrode of $50 \mu \mathrm{m}$ in diameter at $15 \mathrm{mVs}^{-1}$ positioned at $80 \mu \mathrm{m}$ from the steel substrate in abiotic (curve a) and biotic (curve b) conditions for $72 h$ and $24 h$ after inoculation, respectively. The curves presented are a zoom of the anodic domain.

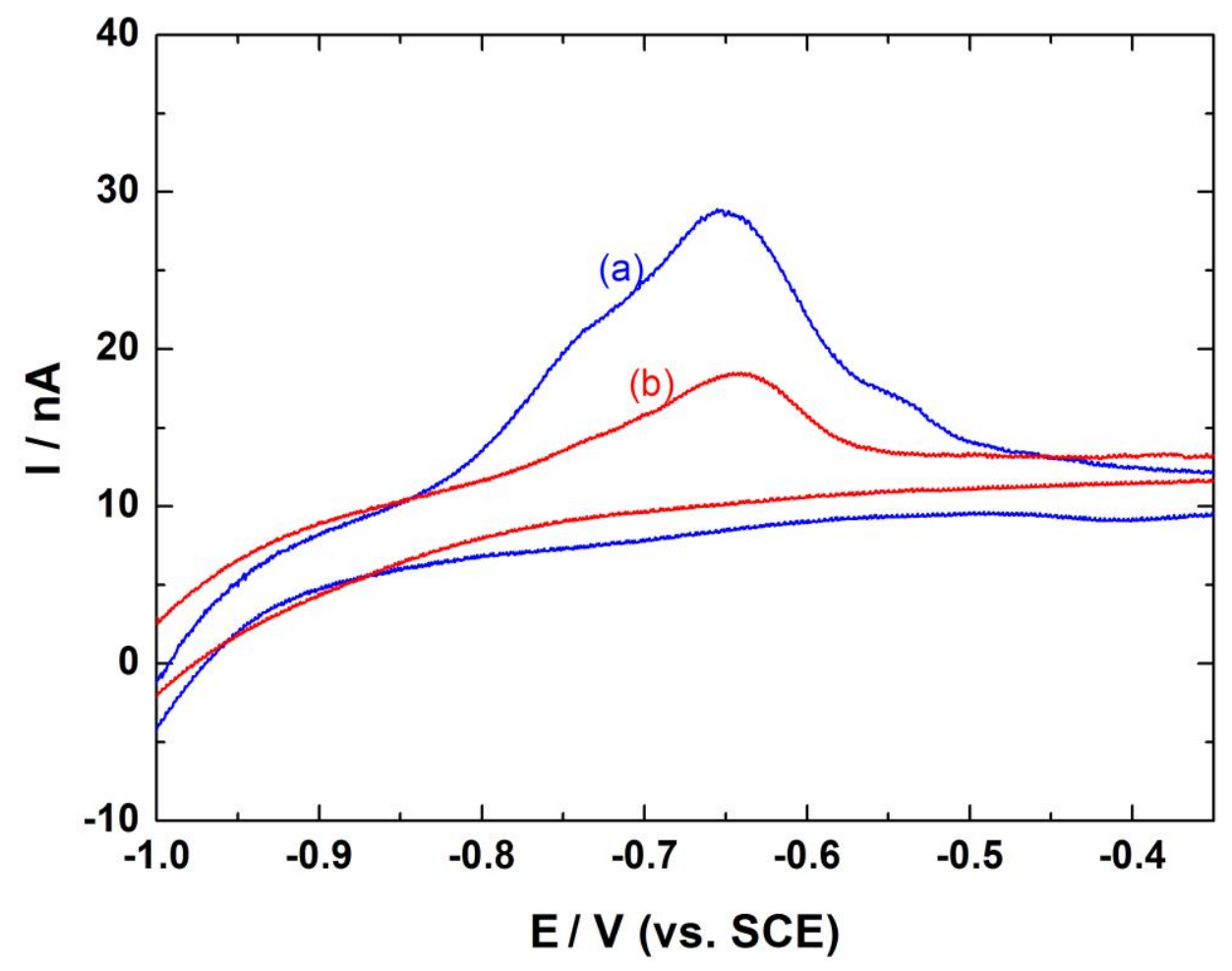


Figure 3: Evolution of the amount of $\mathrm{H}_{2}$ oxidized (given as charge) at the Pt microelectrode during the backward scan of potentials as a function of the tip-to-substrate distance. The red curve was measured in abiotic conditions and the blue one in biotic conditions. Symbols are experimental measurements.

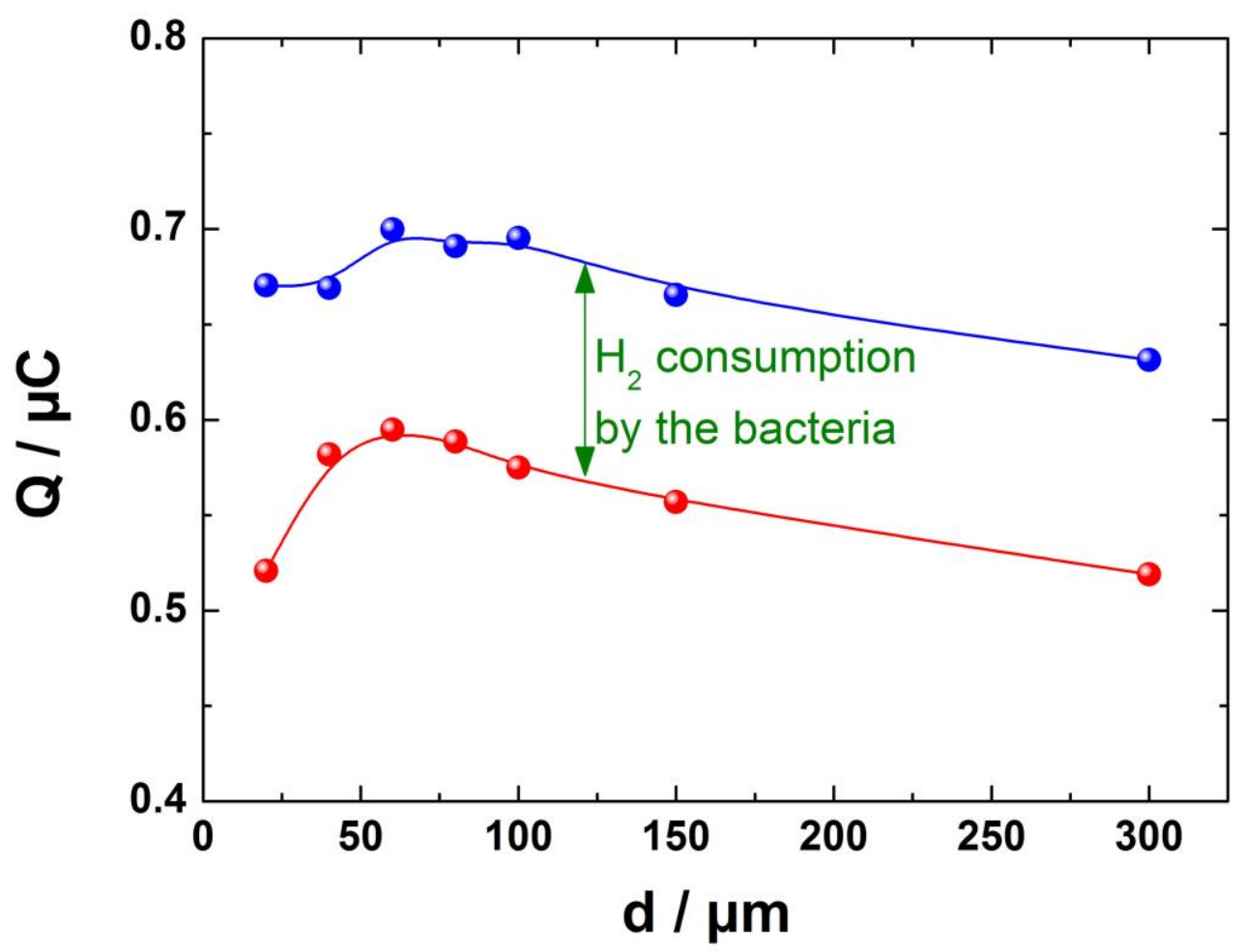


Figure 4: Evolution of the global electrochemical impedance diagrams at the corrosion potential in presence of bacteria with time as parameter. Electrode surface $A=0.79 \mathrm{~cm}^{2}$.

- before inoculation; $\bullet$ after $4 \mathrm{~h} ; \triangle \operatorname{after} 44 \mathrm{~h} ; \boldsymbol{\nabla}$ after $68 \mathrm{~h} ;>$ after $93 \mathrm{~h} ;<$ after $116 \mathrm{~h}$

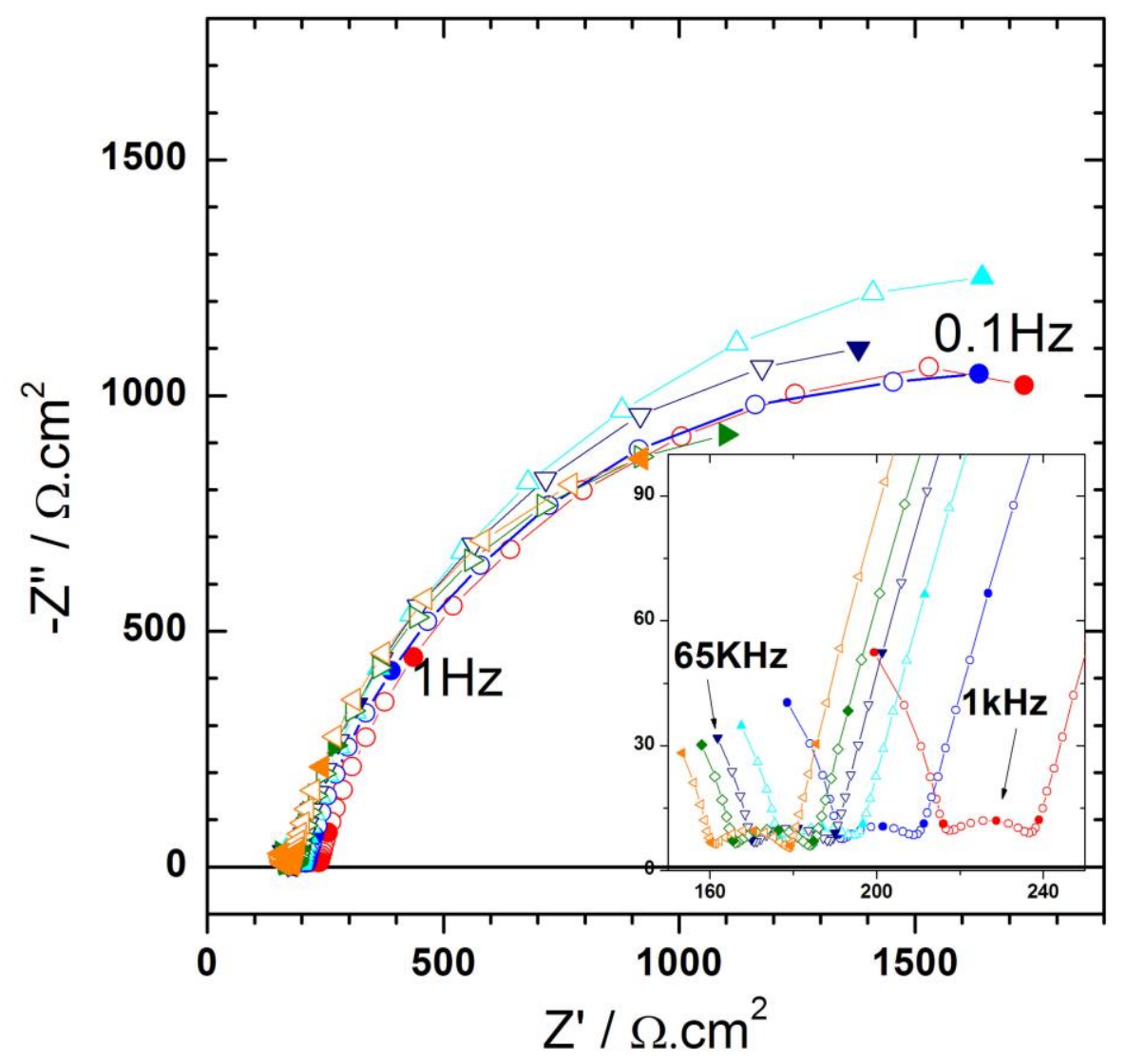


Figure 5: Evolution of the capacitance in high frequency range.

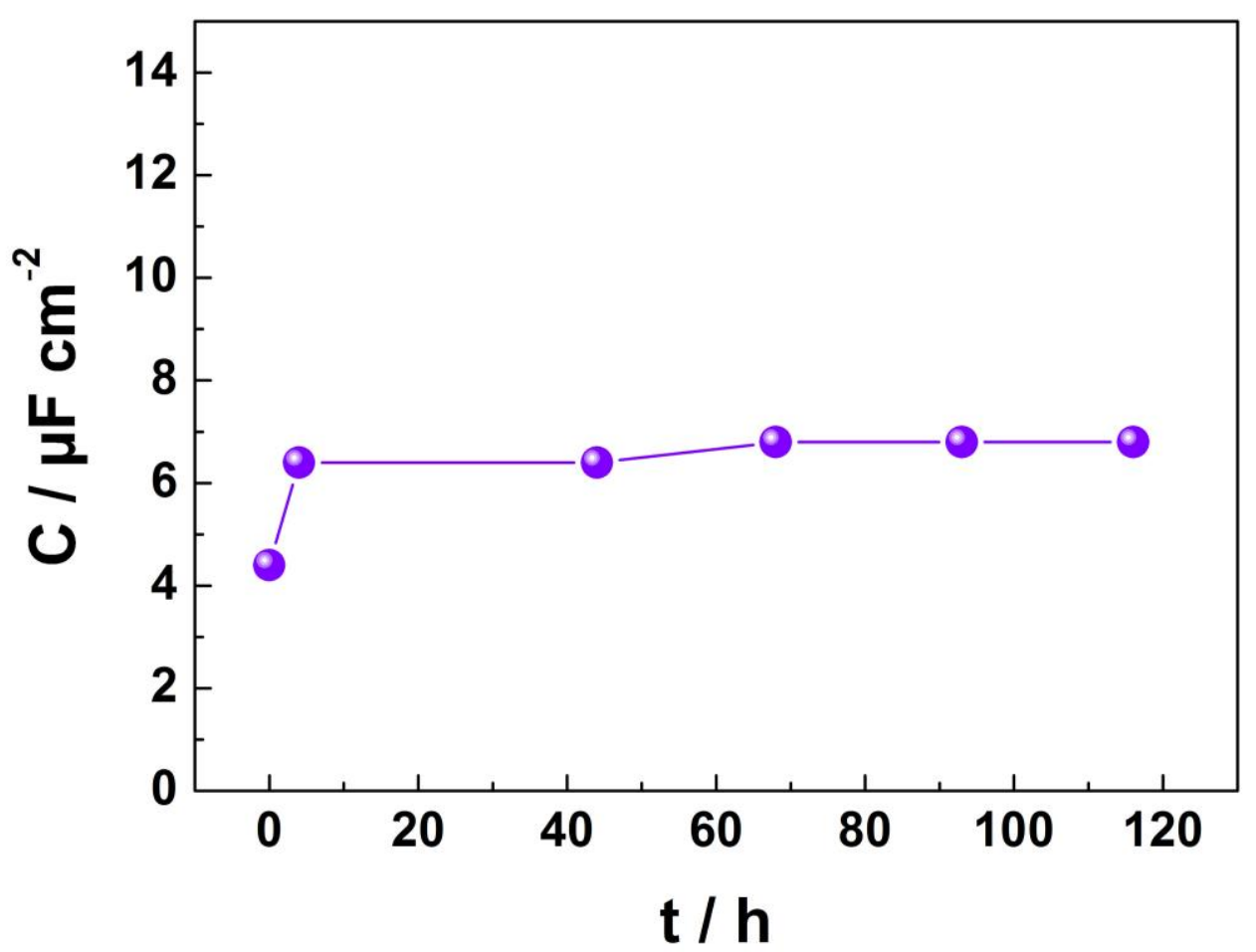


Figure 6: Evolution of the capacitance in low frequency range.

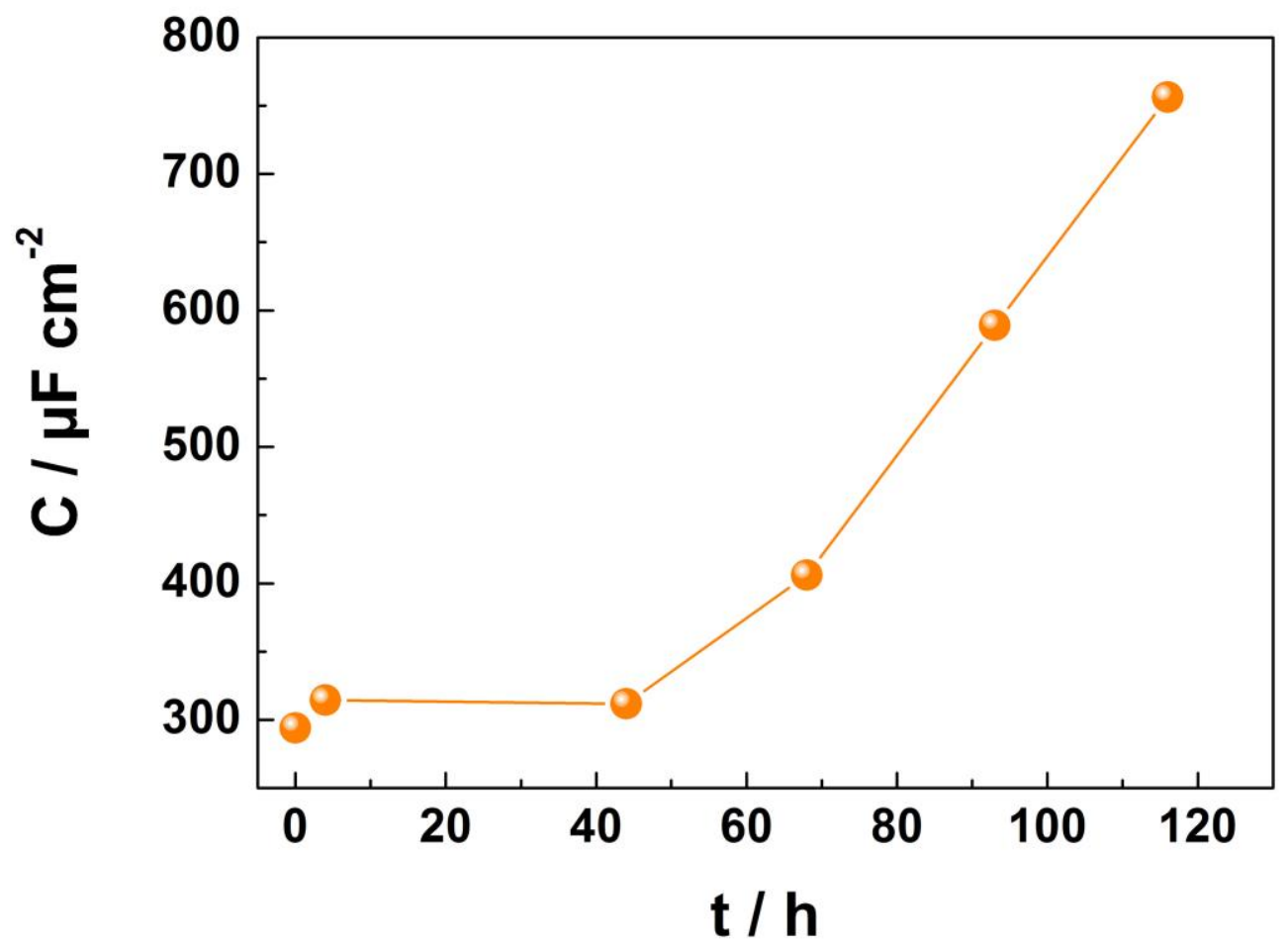


Figure 7: Evolution of the local electrochemical impedance diagrams in presence of bacteria with time as parameter. (a) at the electrode centre, and (b) at $1 \mathrm{~mm}$ from the electrode centre. Electrode surface $A=0.79 \mathrm{~cm}^{2}$. $\bigcirc$ before inoculation; $\Delta$ after $1 \mathrm{~h} ; \nabla$ after $4 \mathrm{~h} ; \diamond$ after $44 \mathrm{~h}$;

after 68h; after $93 \mathrm{~h} ;$ i after $116 \mathrm{~h}$
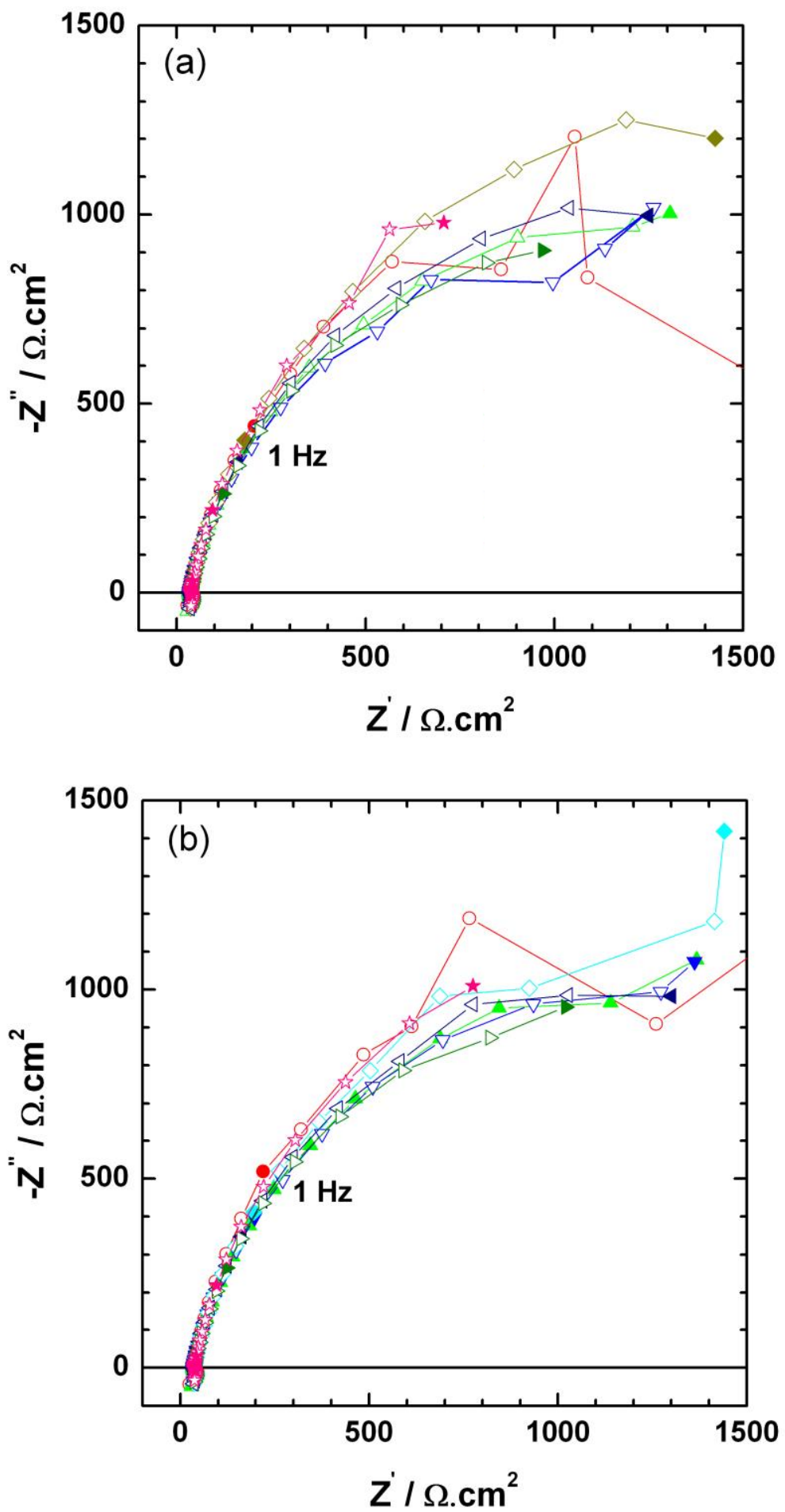
Figure 8: SEM image of the carbon steel substrate after 5 days of immersion in M1 solution in biotic conditions.

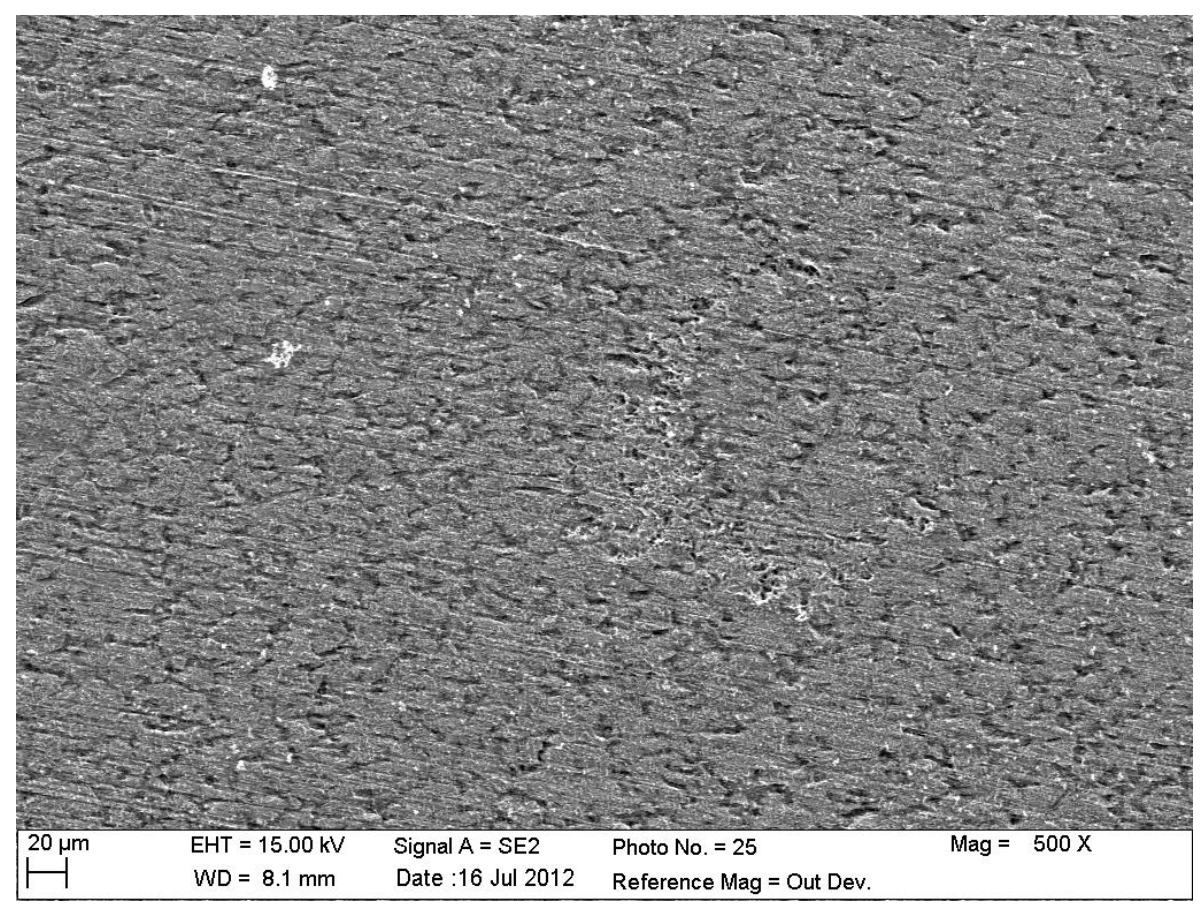

